Miroslav Radonjić

Sterijino pozorje, Novi Sad, Srbija

miroslav.radonjic@pozorje.org.rs

(D) https://orcid.org/0000-0003-0163-1683

\title{
Savremeni dramski tekst u Srbiji (1995-2015) - od eskapizma do društvenog angažmana
}

\section{Contemporary drama in Serbia (1995-2015) - from escapism to social engagement}

Sažetak: Savremena srpska dramska književnost u periodu od dvadesetak godina (1995-2015) doživela je svojevrsnu renesansu, pojavom nove generacije autora, čije su nezvanične predvodnice bile Biljana Srbljanović i Milena Marković. Oni su na beskompromisan i umetnički relevantan način ušli na velika vrata u domaća pozorišta, baveći se temama koje su bile duboko uronjene u savremeni društveni i istorijski trenutak, neopterećeni ideološkim nasleđem, ali duboko svesni konteksta vremena i prostora u kojima žive. Prateći moderne tokove u evropskoj dramaturgiji, preuzimali su pojedine obrasce i uspešno ih prilagođavali lokalnim okvirima i sopstvenim poetičkim nazorima. Uz njih, sveukupnoj pozitivnoj slici o srpskoj drami na kraju dvadesetog i u prvim decenijama dvadeset prvog veka, doprinosili su već etablirani autori, verni nešto tardicionalnijim literarnim postupcima i klasičnijem dramskom pismu. Teme i motive svojih komada neretko su pronalazili $\mathrm{u}$ istoriji, mitovima i legendama, povezujući ih sa današnjicom istančanim i inteligentnim promišljanjem o univerzalnim civilizacijskim pojavama, oplemenjujući drame metaforičko-alegorijskom stilizacijom.

Ključne reči: društveni angažman, eskapizam, savremena srpska drama, istorija, ideologija

Summary: Contemporary Serbian dramatic literature in the period of about 20 years (1995-2015) has experienced a certain kind of Renaissance, with the emergence of a new generation of authors, whose unofficial leaders were Biljana Srbljanović and Milena Marković. In an uncompromised and art-relevant way, they entered through the big doors into local theaters, dealing with topics that were deeply immersed in the contemporary social and historical moment, unburdened by ideological legacy, but deeply aware of the context of the time and space in which they live. Following modern trends in European dramaturgy, they have integrated individual patterns and have successfully adapted them to local frames and their own poetic views. Together with them, the already established authors contributed to the overall positive image of the Serbian drama at the end of the twentieth and the first decades of the twenty-first cen- 
tury, loyal to somewhat more traditional literary procedures and a more classic drama script. They often found the themes and motives of their pieces in history, myths and legends, linking them with the present day, with a sophisticated and intelligent reflection on universal civilizational phenomena, enriching drama with metaphoricalallegorical stylization.

Keywords: social engagement, escapism, contemporary Serbian drama, history, ideology

Sredinom devedesetih godina prošlog veka, Srbija je trpela posledice krvavog raspada Jugoslavije, ratova i međunarodnih sankcija u svim sferama društvenog života. Najdrastičniji efekti osećali su se, naravno, u ekonomiji zemlje, ali i drugi aspekti bili su, u većoj ili manjoj meri, opterećeni prethodnim dešavanjima. Umetnost i kultura, uprkos svemu, ipak su pokazivale neverovatnu vitalnost i kreativnu energiju, što se može okarakterisati i kao svojevrsni otpor sveopštem haosu, bezumlju, povampirenom šovinizmu, međunacionalanoj mržnji, verskoj netoleranciji i svim drugim patološkim pojavama koje su dovele do urušavanja Jugoslavije. Tragedija jedne, do tada cenjene i ugledne evropske zemlje, dovela je do niza katastrofalnih događaja, koje će Srbija, nažalost, nastaviti da proživljava sve do početka dvadeset prvog stoleća. Inflacija, nezabeležena u istoriji, dostigla je svoj maksimum 1993, kada je država bila pred potpunim kolapsom, a višedecenijski građen sistem vrednosti potpuno se urušio. U tom beznađu, ono što je još uvek čuvalo duhovne vrednosti zajednice i bilo, gotovo u doslovnom smislu, poslednja slamka spasa za građansko društvo i njegove ideale, pronalazilo se u nevelikom broju umetnika i institucija kulture, čiji je angažman doprineo kakvom-takvom očuvanju ljudskog dostojanstva i integriteta. Veliku ulogu u tom procesu imali su, između ostalih, dramski autori i pozorišni stvaraoci. Ono što iz današnje perspektive i sa nevelikom, ali ne i beznačajnom istorijskom distancom, možemo, s razlogom tretirati kao fenomen, umnogome je utvrdio pravce razvoja srpske drame i teatra uopšte $u$ narednih tridesetak godina. Poslednja decenija prethodnog veka iznedrila je generaciju dramskih pisaca rođenih između 1970. i 1980. godine, a njihov neformalni predvodnik je Biljana Srbljanović. Uz nju, taj novi talas autentičnih stvaralaca činili su Milena Marković, Uglješa Šajtinac, Maja Pelević, Milena Bogavac, Filip Vujošević, Dimitrije Vojnov. Generacijski su im bliski i vrlo interesantni Danica Nikolić Nikolić i Željko Hubač. Nešto kasnije pridružuju im se Dušan Spasojević, Fedor Šili, Olga Dimitrijević, Petar Mihajlović, Tanja Šljivar. Naravno, na srpskoj pozorišnoliterarnoj sceni uveliko su prisutni i već etablirani autori, kao što su Vida Ognjenović, Dušan Kovačević, Nebojša Romčević, Siniša Kovačević, Stevan Koprivica, uz poznatog filmskog reditelja i scenaristu Gorana Markovića, 
koji počinje da piše i za pozorište'. Činjenica je da dramsko pismo u Srbiji, naročito od pojave Biljane Srbljanović i Milene Marković, dobija poseban zamajac, a nije beznačajan ni prodor u evropski pozorišni prostor. Prvi komadi Biljane Srbljanović duboko su uronjeni u turobnu stvarnost i u tom smislu mogu se označati kao izrazito društveno angažovani. Ona je na najbolji način iskoristila tadašnji političko-ideološki kontekst, kao svojevrsne "kulise“ u čijim okvirima i specifičnoj, pomalo klasutrofobičnoj i mračnoj atmosferi, konstruiše vrlo ubedljive sudbine svojih likova, vešto izbegavajući koketiranje sa dnevno-političkim banalnostima, što je brzo prepoznato i u srpskim, ali i u mnogim evropskim i svetskim teatrima. Pogotovo su zanimljiva tumačenja i postavke drama kao što su Beogradska trilogija, Porodične priče ili Supermarket u inostranstvu. Očigledno je da su, pored umetničkih razloga i estetskih dometa u tim tekstovima, kritički intonirani tonovi usmereni prema režimu Slobodana Miloševića, takođe uticali na međunarodni uspeh ove autorke. U kasnijim ostvarenjima, u zrelijoj stvaralačkoj fazi, tematski krugovi se proširuju, tako da nije više reč o "generacijskim pričama", jezički izraz prevazilazi savremeni, urbani, beogradski žargon, a drame dobijaju novu, u kvalitativnom smislu, puniju žanrovskostilsku dimenziju (Amerika, drugi deo; Skakavci; Barbelo, o psima i deci). Značaj Biljane Srbljanović za srpsku dramaturgiju ne može se posmatrati samo kroz njen dokazani spisateljski talenat, odnosno uspešne predstave nastale po delima ove autorke, več i time što je uticala na ozbiljnije otvaranje teatara za mlađe dramske pisce. Srećna okolnost koja je taj proces u punoj meri osnažila i ubrzala zove se Milena Marković. Iako je u prve dve drame i Markovićeva otelotvorila savremeni svet jedne generacije, sa svim obeležijima epohe u kojoj živi i stvara (Paviljoni i Šine), ipak je prisutan maštovit otklon od realnosti, dok će u sledećim tekstovima pokazati potpuno različitu poetiku i dramski senzibilitet. Krajnje autentične, duboko uronjene u istorijsko-mitološko-književnu tradiciju, specifičnog, bezmalo pesničkog izraza, drame Nahod Simeon, Brod za lutke, Suma blista i Zmajeubice označile su novi tok u razonovrsnim dramaturškim, tematskim, žanrovskim i stilskim osobenostima koje su definisale razvoj srpske dramske literature. Nahod Simeon u tom smislu predstavlja jedan od njenih umetničkih vrhunaca. Poigravajući se sa tematikom incesta, obrađenom još u grčkom mitu i Sofoklovoj tragediji o Edipu, kasnije u narodnoj epskoj poeziji i istoimenom komadu Jovana Sterije Popovića, rodonačelnika srpske dramske književnosti sredinom devetnaestog veka, Markovićeva kreativno preispituje ne samo tradicionalne književne motive, već i dramaturške obrasce, tvoreći

${ }^{1}$ Većina navedenih autora zastupljeni su u dvotomnoj Antologiji najnovije srpske drame, priređivači V. Jezerkić, S. Jovanov: Predsmrtna mladost i Istorija \& iluzija. Novi Sad, Sterijino pozorje, 2007. 
delo izrazite žanrovske heterogenosti, od komedije, preko melodrame do tragedije, uz neobičan i efektan pesnički izraz, na granici poezije i proze. Priča prati Simeonovo odrastanje i suočavanje sa fenomenima savremene civilizacije, uz ironijski odmak od stereotipa svakodnevice, sve do tragične spoznaje o incestuoznoj vezi sa rođenom majkom. Bitan elemenat dramaturškog postupka autorke jesu pesme i stihovi koje izgovaraju likovi, ili obrazuju nekonkvencionalne didaskalije, odnosno, preciznije rečeno, komentare, tvoreći pri tome, vrlo upečatljivu atmosferu, prepoznatljivu i u drugim njenim tekstovima. To je najuočljivije i najdoslednije sprovedeno u Brodu za lutke, bez ikakve sumnje, antologijskoj drami². Žanrovski iskorak ka, uslovno govoreći, fantazmagoriji isprepleten je na strukturnom i suštinskom nivou, sa motivskim i konstruktivnim segmentima bajki (Snežana, Ivica i Marica, Zlatokosa...). Ima ovde, naravno, i obrisa melodrame, komičnih pasaža i tragičnih epizoda, uz već prepoznatljiv jezgrovit, poetski izraz, što Milenu Marković izdvaja kao jedinstvenu pojavu u srpskoj drami i pozorištu. Osobenosti njenog rukopisa obeležava i jasna distanca prema ideološko-političkoj aktuelnosti, odnosno nastojanje da u univerzalnim kategorijama i pitanjima ljudske egzistencije, odnosa prema stvarnosti, istoriji, religiji i kompleksnim društvenim pitanjima pronalazi inspirativnu građu za suverenu i beskompromisnu umetničku nadgradnju, što karakteriše njen ukupni literarni angažman, pesnički i dramski, u značenjskom i vrednosnom poimanju.

„Drugi talas" mlađih dramaturga (Maja Pelević, Milena Bogavac, Dimitrije Vojnov i Filip Vujošević) višestruko je interesantan. Svi su studirali $\mathrm{u}$ istoj klasi dramaturgije na Fakultetu dramskih umetnosti u Beogradu. Većina ih je (osim D. Vojnova, koji se posvetio filmskoj kritici i pisanju scenarija) učestvovala u Projektu Nova drama (Nada), pokrenutom pri Narodnom pozorištu u Beogradu, kasnije nastavljenom u Jugoslovenskom dramskom pozorištu Beograd, sa dramaturgom Milošem Krečkovićem kao mentorom, koji im je omogućio uvid u savremene evropske dramaturške tokove i prakse. Ova generacija autora delimično je stvarala pod uticajem neobrutalističke drame (Džon Osborn, Mark Rejvenhil, Sara Kejn, Marijus fon Majenburg, Vasilij Sigarov) ${ }^{3}$, prilagođavajući se lokalnom ambijentu, mentalitetskim oso-

${ }^{2}$ Milena Marković je za Nahoda Simeona, Brod za lutke i Zmajeubice dobila nagrade za najbolji tekst, a za Šine specijalnu nagradu za tekst drame na najprestižnijem pozorišnom festivala u Srbiji - Sterijinom pozorju, koje se već 64 godine održava u Novom Sadu.

3 “Autori rođeni između 1975. i 1982. godine, Slobodan Vujanović, Ivan Pravdić, Milena Bogavac, Maja Pelević, Filip Vujošević, Milan Marković i drugi, mnogo kasnije su praktikovali ovu formu, stil, tematiku. Jedno od mogućih objašnjenja za takvu situaciju jeste činjenica da su ovi autori prošli kroz radionice projekta NADA (Nova drama), neke vrste baze za novo dramsko pisanje, organizovane u beogradskom Narodnom pozorištu (2002-2003), uz podršku Britanskog saveta. U okviru Nove drame je, između ostalog, 
benostima, društvenim okolnostima. Njihov stil i jezički izraz, kao i tematske preokupacije, proisticali su iz beogradskog žargona i urbanog miljea, tako da je ono što se u evropskoj drami devedestih godina dvadesetog veka, nazivalo "dramaturgijom krvi i sperme“, transformisalo u nešto izmenjenu srpsku verziju ovog toka globalnog dramskog pisma. Pisci ove generacije udaljavaju se od ideoloških obrazaca, tradicionalnih narativa, klasične dramaturške strukture i forme, stvarajući komade koji uzimaju u obzir dominaciju masovnih medija, potrošačke kulture, razvoj društvenih mreža i virtuelnih platformi. Najproduktivnija i najintrigantnija autorka među njima je Maja Pelević. Od desetak napisanih, objavljenih i postavljenih na sceni, Pomorandžina kora i Ja ili neko drugi ponajbolje oslikavaju specifičan dramaturški postupak ove autorke. Pomorandžina kora na tematskom nivou, na prvi pogled, donosi jednostavnu i potencijalno relaksirajuće-duhovitu priču, sa primesama feminističkog pogleda na svet o fenomenu ženske lepote (pomorandžina kora je eufemizam za celulit), dehumanizovanog savremenog potrošačkog društva, muško-ženske odnose u svetlu virtuelne komunikacije, za koju bi se brzopleto moglo zaključiti da nema većih umetičkih pretenzija. Ali, upravo ta nepretencioznost, uz upečatljiv jezički izraz, formalnostrukturne elemente (tekst je oblikovan kroz smenjivanje dijaloga, monologa, komentara i naracije), promišljeno korišćenje tragikomičnih i melodramskih obrazaca, doprinose nesumnjivim estetskim dometima drame. Ja ili neko drugi polazi od istinite priče o otmici devojčice u Austriji, njenom zatočeništvu dugom deset godina, begu od otmičara i povratku porodici. Maja Pelević vrlo vešto i drmaturški ubedljivo koristi autentične događaje i ugrađuje ih u tematsko-idejno tkivo svojih drama. Njen stil odlikuje sveden, gotovo ogoljen izraz, upečatljivi i plastično oblikovani, pogotovo ženski likovi. Ova autorka stvarala je, a i dalje je to slučaj, pod uticajem savremenih tokova evropske dramaturgije, uz podrazumevano prilagođavanje lokalnom društvenom i umetničkom kontekstu. Nije to, naravno, puko preslikavanje poetičkih i dramaturških modela iz nemačke, ruske ili engleske moderne dramske literature, već svojevrsna kreativna nadgradnja, što se pokazalo veoma zanimljivom i plodotvornom praksom za čitav niz pisaca bliske generacije. Jedna od njih je Milena Bogavac sa bogatim dramskim i pesničkim opusom, ali i naročitim pozorišnim angažmanom, koji zadire u šire slojeve

organizovan dolazak menadžera i pisaca Royal Courta, koji su vodili razgovore i radionice sa srpskim piscima, prevođeni su komadi britanskih pisaca (Rejvenhila, Nilsona, Martina Krimpa), što je sigurno uticalo na profesionalni razvoj mladih pisaca iz Srbije. Dakle, u Srbiji je od 2003. godine, a najviše u 2005. i 2006. godini, došlo do masovnije produkcije tekstova autora ove najmlađe generacije, koji se uklapaju u neobrutalistički rukopis, po strukturi, temama, stilu.“ A. TAsić: Otvorene rane - telo u neobrutalističkoj drami i pozorištu. Beograd, Čigoja štampa, 2009. 
osobenog građanskog bunta protiv tradicionalnih, ili bolje rečeno konzervativnih stavova o samoj suštini teatarske umetnosti, o manjinskim pravima, položaju žena u savremenom društvu, odnosu nezavisne scene i institucionalnih pozorišnih kuća. Stoga nije neobično da je ona tokom druge polovine devedestih i u prvoj deceniji dvehiljaditih godina prednjačila u istraživačom pristupu, odnosno kritičkom sagledavanju uobičajenih dramaturških postupaka, promišljenom odabiru "osetljivih" tema za tek uspostavljeno srpsko demokratsko društvo, često balansirajući na oštroj granici između performativnog i pozorišnog karaktera tekstova, kao osobenih otvorenih literarnih platformi-predložaka za scensku igru, što je pogotovo bilo vidljivo u realizovanim predstavama. Krajnje neuobičajena tema njene drame North force o navijačkoj skupini fudbalskog kluba Crvena zvezda „Delije“ označena je kao "tragedija za poneti“. Ovo ironično žanrovsko, donekle i autopoetičko određenje, ima svoje uporište u samoj strukturi komada. Naime, fanatične pristalice beogradskog kluba prikazane su, uslovno govoreći, kao pandan horu u grčkoj tragediji, u smislu kolektivnog lika, unutar koga ipak egzistiraju pojednici sa svojim različitim socijalnim, obrazovnim, generacijskim obeležijima. Ipak, oni u velikoj meri funkcionišu unutar jasno definisane grupe, povezani skoro patološkim nacionalističkim fanatizmom i samodestruktivnom strašću prema jednom fudbalskom klubu. Za razliku od Milene Bogavac, koja u književno-dramskom i pozorišnom aktivizmu polazi od lokalnih tema i negativnih pojava iz najbližeg okruženja, Dimitrije Vojnov se u tekstu Velika bela zavera bavi globalnim fenomenom proizašlim iz tragične sudbine rok ikone Kurta Kobejna, pevača legendarne grupe „Nirvana“. Pseudobiografska drama o umetniku čiji je kratak život nakon samoubistva prešao u sfere urbane legende otvara pitanja ne samo o ličnim psihičkim krizama izazvanim nemogućnošću suočavanja sa surovim svetom muzičke industrije i teretom slave, nego problematizuje pojedine aspekte savremene civilizacije utemeljene na lažnim vrednostima, manipulacijama, obmanama i beskrupuloznom društvu profita kao isključivom i jedino poželjnom idealu. U takvom svetu svaka pobuna unapred je osuđena na neuspeh, a pojedinac, prototip „buntovnika bez razloga“ neumoljivo stremi ka svom predodređenom kraju. Žanrovsko preplitanje elemenata krimi zapleta i satire umnogome doprinose umetnički visokim dometima Velike bele zavere. I kod četvrtog predstavnika iste klase dramaturgije na Fakultetu dramskih umetnosti u Beogradu, Filipa Vujoševića, može se konstatovati da se istorijske, političke i ideološke pojave iz dalje ili nešto bliže prošlosti, odnosno sadašnjice, ne transponuju po svaku cenu u tematske okvire njegovih drama. Svakako da su prisutni, pre svega u specifičnoj atmosferi i širem društvenom kontekstu unutar kojih se odvija radnja. Međutim, Vujošević se, slično pomenutim kolegama, fokusira na „male" priče i sudbine marginalizovanih pojedinaca, bez prevelikih ambicija da se bavi „epskim“ temama ili posledicama ideološko-političkih zabluda 
prethodnih generacija. HalFlajf na prvi pogled otelotvoruje jednostavnu situaciju - beg iz turobne svakodnevice u virtuelni svet video-igre "Counter Strike“. Nekoliko mladih ljudi zamenjuje surovu stvarnost ulaskom u paralelnu dimenziju još izraženije agresivnosti i autodestrukcije (video-igra prepuna je scena ubijanja, smrtonosnog oružja i krvavih obračuna). Ipak, ova naizgled jednodimenzionalna dramska situacija već u uvodnoj sceni grana se na nekoliko paralelnih tokova unutar kojih se prepoznaju životne dileme, nedoumice, nesigurnost, neophodnost emotivno-psihološkog sazrevanja i egzistencijalno važne inicijacije, odnosno prelaska iz infantilnog okruženja u svet odraslih. U klaustrofobičnom ambijentu nedovršene i nefunkcionalne stanice nepostojećeg beogradskog metroa, paradoksalne paradigme posrnuća jedne evropske metropole, odvija se depresivni proces odrastanja likova komada. Završetak ne nudi nikakav izbor. Nema izlaska iz tame apsurdne stanice metroa.

MILENICA: Nemoj da se bedačiš, Krivi.

KRIVI: Ne bedačim se. To je samo turnir. Ionako su pukli.

MILENICA: Kako samo turnir? Tako smo se nadali.

KRIVI: To mi u životu ništa ne znači. Jebeš turnir.

Pauza.

KRIVI: A mogli bismo da udemo u proi autobus i vozimo se jednu stanicu $i$ da se deremo na ljude?

MILENICA: A što?

KRIVI: Da se pobunimo.

MILENICA: Protiv čega?

KRIVI: Ne znam. Protiv sistema.

MILENICA: A što?

KRIVI: Pojma nemam ${ }^{4}$.

Dijalog na samom kraju Vujoševićevog dramskog teksta verovatno na najupečatljiviji način ilustruje razmišljanja i stav ove generacije autora. Oni ne donose konačni moralni sud o gresima onih pre njih, niti ih interesuje da ideologija bude dominantna tema njihovog literarno-dramaturškog angažmana. Duboko svesni svih okolnosti društva u kojem žive, progovaraju o uzaludnosti pokušaja "generacije $X^{\prime \prime}$ da se izbore za svoje mesto u dehumanizovanom svetu, o skrajnutima i marginalizovanima koji nastoje da uskoče u zadnji voz sa imaginarne stanice nepostojećeg metroa mutne sadašnjice $u$ isto tako neizvesnu budućnost.

U tom periodu izdvaja se još nekoliko pisaca čija su dela bila osnova za značajne predstave srpskih pozorišta. Uglješa Šajtinac sa dve žanrovski, stilski i tematski sasvim različite drame Pravo na Rusa i Hadersfild promoviše priličan otklon od tada preovlađujućih dramaturških praksi. Prvi komad

\footnotetext{
${ }^{4}$ Filip Vujošević: HalFlajf. U: Predsmrtna mladost..., str. 223-224.
} 
odlikuje tradicionalna, na momente i konzervativna škola pisanja, što ga svrstava $\mathrm{u}$ apartnu pojavu srpske dramske književnosti s kraja dvadesetog veka. Reč je o priči melodramskog karaktera o ljubavi između vojvođanske, odnosno, banatske seljančice i interniranog ruskog vojnika u vreme Prvog svetskog rata. Radnja se odvija u koloritnom ambijentu banatske ravnice i ruske stepe, bez uspostavljanja nekih jasnijih aluzivnih poveznica sa ratnim iskustvima sa prostora bivše Jugoslavije devedesetih godina minulog stoleća. Takav beg od stvarnosti prisutan je i kod nekolicine drugih autora, ali je interesantno da se on pronalazi u diplomskom radu mladog stvaraoca, praktično na početku karijere. Već naredni tekst Hadersfild otkriva drugačiji književno-dramaturški senzibilitet. I po formi, strukturi, žanrovskom određenju, ali i po sadržaju Šajtinac se približava tadašnjem trendu savremene domaće drame, zadržavajući umnogome autentičan rukopis. Radi se o tipičnoj generacijskoj drami u čijem središtu su sudbine tridestogodišnjaka koji su mladost proveli $u$ ruiniranom i traumatičnom ex-jugoslovenskom društvu urušenog vrednosnog sistema, obesmišljenih institucija, ekonomsko-socijalnom kolapsu, moralnoj i ljudskoj degradaciji. Povratak jednog od njih iz malog britanskog grada u provinciju, reminiscencija na nepovratno izgubljene snove i ambicije o nekom boljem i srećnijem životu, otrežnjujuće suočavanje sa besperspektivnošću, boje atmosferu drame tamnim valerima. Jezički izraz je do krajnosti sveden, uz obilje psovki, što doprinosi građenju dramskih situacija i postupku karakterizacije likova. Šajtinčevom klasičnijem dramaturškom prosedeu blizak je i Željko Hubač. On se nije tako lako povodio za mnogobrojnim „modernim“ pojavama u evropskoj savremenoj drami, već je ostao dosledan u nastojanjima da u komadima zadrži razvijenu priču, kauzalnost događaja, precizno definisane likove i njihove međusobne odnose. Bizarno je u tom smislu Hubačeva najuspešnija drama. Smeštajući osebujne protagoniste, sve odreda istraumatizovane i isfrustrirane večite gubitnike, u soliter, preciznije na krov, jedan stan višespratnice i u kafić u prizemlju, stvarajući tako metaforu hijerarhije celokupnog društva, autor problematizuje besmisao i apsurde sa kojima su suočeni likovi u borbi za goli život. Stoga je smrt, uzrokovana ubistvom ili samoubistvom, kao logična posledica bizarnih okolnosti koje su isprepletene $\mathrm{u}$ tri priče ispunjene autodestruktivnim ostrašćenostima, porodičnim nasiljem, seksualnom eksploatacijom, kriminalnim miljeom, zapravo jedini mogući izlaz iz solitera predvorja pakla.

Pregled onoga što se dešavalo u srpskoj dramskoj književnosti krajem prošlog i početkom novog veka bio bi nepotpun bez pominjanja Danice Nikolić Nikolić, Dušana Spasojevića, Fedora Šilija, Petra Mihajlovića i Olge Dimitrijević. Sava Savanović - vampirska simfonija Danice Nikolić Nikolić jeste izrazito duhovito poigravanje sa mitološko-literarnom tradicijom koja obrađuje temu prvog srpskog vampira Save Savanovića. Pisan u formi epskog 
deseterca, komad predstavlja pravo žanrovsko-stilsko osveženje i otkriva samo jedan od mogućih modela preispitivanja srpske literarne baštine, uz inventivan parodijsko-ironični otklon. Osim Vampirske simfonije, i druge najbolje drame ove spisateljice vremenski i prostorno izmeštene su iz savremene urbane sredine. To je slučaj i sa Odumiranjem i Zverinjakom Dušana Spasojevića, čiji junaci svoju borbu sa ličnim demonima vode u ruralnom ambijentu. Radnja u oba teksta odvija se u vremenu tranzicije, obeleženom sumnjivom privatizacijom velikih društvenih kompanija, odsustvom empatije, moralnom degradacijom, ratnim i poratnim dešavanjima, traumatičnim posledicama raspada zemlje. Kompleksni porodični odnosi i generacijski sukob čine osnovne motivske elemente Spasojevićevog dramaturškog postupka. Na drugoj strani, Olga Dimitrijević (Radnici umiru pevajući i Kako je dobro videti te opet) i Petar Mihajlović (Radnička hronika), na autentičan način dosežu kritički intoniran društveni angažman, upečatljivo oslikavajući radničke i penzionerske egzistencijalne probleme tokom i nakon (nikada) završenog tranzicionog perioda u Srbiji. Dok je Olga Dimitrijević otvorenija za eksperimentisanje na planu forme i jezičkog izraza, dotle je Mihajlović suzdržaniji i bliži klasičnoj dramskoj strukturi. Iako im je po godinama blizak, Fedor Šili teško može da se svrsta u estetičko-poetički obrazac prethodnih autora. Ne samo zbog Čarobnjaka, već i najnovije drame Noćna straža (radnja smeštena $\mathrm{u}$ tridesete godine dvadesetog veka na vodviljski način obrađuje dekadentni život beogradskog visokog društva, uz neizostavno spletkarenje, manipulacije, prevare i obmane). Psudobiografski Čarobnjak samo polazi od intrigantnog i umetnički uzbudljivog života Tomasa Mana i njegovog bogatog književnog opusa. Međutim, Šili ne piše biografsku niti istorijsku dramu. Uplićući u siže Manove likove i maštovitu fikciju, činjenice povezane sa buđenjem i razvojem nacionalsocijalističe ideologije u Nemačkoj, odnose sa bratom Hajnrihom, položaj i značaj umetnika u društvu, stvaranje u komplikovanim ideološko-političkim i istorijskim okolnostima, Šilijev Čarobnjak efektno spaja iluziju, stvarnost, snoviđenja i dokumentarističku građu.

Mlađa generacija dramskih pisaca je, uz retke izuzetke, stvarala pod uticajem aktuelnih događaja, ali je izbegavala da istorijski i ideološko-politički kontekst prevagne. Oni su, takođe, u većoj ili manjoj meri pratili stilsko-poetička kretanja u savremenoj evropskoj dramaturgiji, prilagođavajaći ih, nekada vrlo uspešno, a ponekad manje vešto, lokalnim književno-estetskim okvirima. Na osnovu toga može se zaključiti da je ovaj korpus srpske dramske literature $\mathrm{u}$ korelacijama sa neskrivenim i direktnim kritički intoniranim društvenim angažamanom. S druge strane, Vida Ognjenović, Dušan Kovačević, Nebojša Romčević, Siniša Kovačević, Stevan Koprivica i, samo donekle, Goran Marković u svojim najznačajnijim i u umetničkom smislu najvrednijim komadima, kreativno se distanciraju od patoloških pojava iz svakodnevice, tako što teme biraju iz povesno-mitoloških sfera, uz izražen 
metaforičko-aluzivni „beg“ od dnevno-političke banalnosti. I ovde, naravno postoje izuzeci, kao što je pomenuti Goran Marković, koji se u Turneji, bez sumnje njegovoj najboljoj drami, bavi tek nedavno okončanim ratom u Jugoslaviji, u čijem je središtu putešestvije glumačke trupe po sukobima zahvaćenim prostorima. Odnos umetnosti i besmisla krvavog pustošenja i razaranja, obojen crnim humorom i snažnom antiratnom porukom samo su neki od idejno-motivskih nivoa drame. Nisu od društvenih aktuelnosti bežali ni Dušan Kovačević, Nebojša Romčević i Siniša Kovačević, međutim, u najrelevantnijim dramama ovih pisaca primetno je fokusiranje na univerzalnije, opšte, civilizacijske pojave. Tako recimo, Vida Ognjenović inspiraciju traži u daljoj ili bližoj istoriji, mitovima i legendama, ponajpre iz primorskih krajeva današnje Crne Gore, ali i Vojvodine koja je svojevremeno bila deo Austro-Ugarskog carstva. Ona ne piše istorijske drame, iako događaji i ličnosti jesu autentični i bitno su uticali na viševekovna dešavanja na ovim prostorima. Istančan senzibilitet prozne i dramske spisateljice, te osebujna poetika pozorišne rediteljke i iskustvo velikog poznavaoca srpske literarne baštine, oseća se u Jegorovom putu, Don Krstu, Milevi Ajnštajn, a pogotovo u tekstovima iz nešto ranijeg perioda, kao što su Je li bilo kneževe večere ili Kanjoš Macedonović. Tradicionalna dramaturška škola, jezgrovit, istančan i vrcavo duhovit jezički izraz, žanrovska heterogenost, brižljivo građene situacije i karakterizacija likova, glavne su odlike opusa Vide Ognjenović. Činjenica da teme i motive pronalazi u legendama, mitovima ili istoriji nikako ne znači da je reč o anahronim ili arhaičnim ostvarenjima. Upravo suprotno. Pronalazeći univerzalna značenja i vrednosti u nekim već poznatim pričama, tretirajući istoriju kao fenomen koji se ne ponavlja, već u svom kontinuiranom odvijanju otkriva određene sličnosti, pre svega u domenu ideoloških zabluda, političke manipulacije, religijske ili nacionalne ostrašćenosti, mentaliteta pojedinaca ili društveno-socioloških grupa, problematizuje pojave iz našeg vremena, ali ne na direktan, eksplicitan način. Jegorov put je druga drama iz „Budvanske trilogije“ (tematski krug ovih tekstova proističe iz bogate i burne istorije i legendi Bokokotorskog zaliva), koju još čine i Kanjoš Macedonović i Don Krsto. Turbulentna situacija u celokupnoj Evropi 1806. godine, još se kompleksnije ispoljavala u primorskim krajevima današnje Crne Gore. Budva je pod Rusko-crnogorskom upravom, da bi već sledeće godine bila okupirana od strane Napoleonove Francuske. Oslanjajući se na autentični kratki zapis o ruskom monahu, zavetovanom na ćutanje, iz porodice Stroganov, koji dolazi u jedan mali manastir i počinje da pravi put od mora do manastira Praskavica, autorka nadalje stvara pseudoistorijsku priču o sukobu civilizacija, kultura, mentaliteta, običaja na skučenom priobalnom pojasu u kome obitavaju predstavnici prkosnog i ponosnog malog naroda, osuđenog na večitu borbu za slobodu i čuvanje identiteta, jezika, ali i gole egzistencije. Don Krsto je drama zasnovana na životu i delu Krsta Ivančevića, 
sveštenika, učitelja, pesnika, velikog poštovaoca i poznavaoca muzike i pozorišta, autora Ljetopisa Budve iz 1650. godine. Od oskudnih i nepotpunih biografskih podataka, nekolicine Ivančevićevih sačuvanih zapisa o venecijanskom teatru i ponekom istorijskom zapisu, Vida Ognjenović stvara komad o uzaludnoj potrazi za vlastitim identitetom, neravnopravnoj borbi umetnika i humaniste za vrednovanje i poštovanje temeljnih estetskih i umetničkih kategorija, o veri i ljubavi, samoizgnaniku iz prividne sigurnosti zavičaja u veliki, nepoznati svet s ambicijom da dosegne mladalačke ideale ispunjenog i smislenog života. Epilog takve potrage nedvosmisleno je razočaravajući. Slična je sudbina Mileve Ajnštajn u istoimenoj drami o tužnoj sudbini ambiciozne i talentovane naučnice, prve supruge Alberta Ajnštajna. Intrigantnom i višestruko inspirativnom životnom pričom jedne, bez sumnje, velike žene, autorka je počela da se bavi još početkom sedamdesetih godina prošlog veka, što je rezultiralo TV dramom u produkciji Televizije Beograd, da bi je uspešno zaokružila dramskim tekstom konačno završenim i izvedenim na sceni Narodnog pozorišta Beograd krajem dvadesetog stoleća. Milevin i Albertov odnos, upoznavanje na fakultetu u Cirihu, ljubav, brak, njihova deca, narušeni supružnički odnosi i konačni razlaz čine osnovu i okvir za melodramu unutar kojih se Milevino nesebično i samopožrtvovano nastojanje da očuva porodicu, uz odricanje od naučne karijere, prikazuje kao potresna drama jednostavne i iskrene heroine, čija je opsesivna privrženost uzročnik lične tragedije. Porodica kao uzbudljivi mikrosvet jeste glavna tema i u brojnim komadima Dušana Kovačevića. „Osnovna ćelija društva" u Kovačevićevim delima redovno je hendikepirana - nema žena u Maratonci trče počasni krug, Georgina pet godina nosi trudnoću u Radovanu III, beznadežna otuđenost braće Kraj i emotivna senzibilnost njihove sestre Vesele u Klaustrofobičnoj komediji, karikaturalni likovi i apsurdne situacije koje izazivaju trojica braće blizanaca Nos oženjenih trima sestrama bliznakinjama u grotesknim familijarnim odnosima u Lariju Topsonu, tragediji jedne mladosti, senilni i pogubljni Nikola Kos i njegova sestra Divna u dehumanizovanom svetu beskrupuloznog kriminala Doktora Šustera - porodice su koje tako malo liče na stvarne, a tako mnogo govore o stvarnosti ${ }^{5}$. Jedna od karakteristika Kovačevićevog dramaturškog postupka krije su upravo u tome da i ono što je na prvi pogled realno, zapravo nosi fantazmagorične, iracionalne i apsurdno-groteskne obrise. U Doktoru Šusteru dešava se sučeljavanje nestajućeg sveta Alchajmerovom bolešću ophrvanih Nikole Kosa i Divne, alternativne stvarnosti zarobljene izmaglicama sećanja, halucinacija, demencije sa narastajućim crnilom kriminalizovane, amoralne i korumpirane zajednice otelotvorene $u$ policajcu-mafijašu i njegovom bratu višestrukom

${ }^{5}$ Vidi: M. RadonjIć: Sterija u ogledalu XX veka. Novi Sad, Pozorišni muzej Vojvodine, 2006, str. 107. i Begunci iz beznađa. Novi Sad, Pozorišni muzej Vojvodine, 2017, str. 33. 
ubici. Kovačević se u duhu prethodnih antologijskih drama Maratonci trče počasni krug, Balkanski špijun, Sabirni centar, Klaustrofobična komedija i Profesionalac u značenjskom smislu uzdiže iznad lokalno prepoznatljivih obrazaca ponašanja, mentaliteta, ideoloških dogmi. Iako su oni neraskidivi deo srpskog etničko-etičkog miljea, superiornim literarno-dramaturškim umećem, stilsko-jezičkom rafiniranošću, crnohumornim situacijama i smešno-tragičnim likovima ostvaruje univerzalnost poruka, tema i ideja svojih komada. Dok Kovačevićeva inspiracija ishodište redovno ima u najbližem okruženju, a potom se specifičnim postupcima oneobičavanja pretvara u kompleksna, mnogoznačna dela, Nebojša Romčević u Karolini Nojber polazi od intrigantne životne priče nemačke glumice iz sredine osamnaestog veka i njenog beskompromisnog zalaganja za afirmaciju istinskih umetničkih vrednosti. U središtu radnje jeste sukob dva koncepta, prvog koji zastupa Karolinin otac, lakrdijaš Hansvurst, zagovornik nesputanog hedonizma, lake zabave i lakrdije, i drugog, Karolininog opredeljenja, okrenutog prosvetiteljskoj ulozi teatra. Iluzija Karoline Nojber da umetnost ima moć da promeni svet u kojem živi, primitivizam publike isključivo željne jeftine i besmislene zabave, raspršiće se u neminovnom suočavanju sa neumoljivom stvarnošću. Tema odnosa pozorišta i društvene zbilje, odnosno, u širem smislu, srži umetnosti bila je zanimljiva mnogim stvaraocima, tako da Romčević nije usamljen u pokušaju odgonetanja ovog večitog rebusa. Srpska dramska književnost takođe je otvarala to pitanje kroz komade Ljubomira Simovića, Dobrivoja Ilića, Dušana Kovačevića, Vide Ognjenović...Uzimajući u obzir sveopštost umetničko-estetskih sfera, naprosto se podrazumeva da su se autori udaljavali od aktuelnosti i svakodnevice, tražeći kreativna pribežišta u imaginarnim, mitsko-legendarnim ili istorijskim pričama i događajima. Na tom tragu moguće je, ali vrlo obazrivo, konstatovati svojevrsni beg od stvarnosti, što nikako ne znači da ti pisci nisu duboko svesni vremena i prostora u kojima egzistiraju i sa njima uspostavljaju jasne, ne i banalne paralele. Najkarakterističniji primer takvog oblika eskapizma jeste Stevan Koprivica sa „Bokeljskom pozorišnom trilogijom" (Novela od ljubavi, Bokeški D-mol i Betula u Malu Valu). Radi se o melodramama sa komediografskim crtama, u čijem središtu je, sasvim očekivano, ljubavna priča dvoje mladih, čijoj se sreći, po pravilu, suprotstavljaju porodice, konzervativni moralni principi ili nerazumevanje okruženja. Koristeći obrasce renesansnih komedija, bajkovitu atmosferu, šarmantan i nadasve duhovit, pomalo arhaičan jezik crnogorskog primorja, Koprivica oživljava zaboravljenu prošlost Bokokotorskog zaliva i progovara o esencijalnim ljudskim emocijama u vremenu u kojem tako nešto više ne postoji. Međutim, Koprivica je suviše ozbiljan pisac da bi ostao samo na jednodimenzionalnom nivou, pa u tkivo svojih drama on utiskuje i probleme susreta i nerazumevanja različitih kultura, nacionalnih, verskih i staleških pripadnosti, čime otvara širok spektar tema zanimljivih za današnjeg 
čitaoca, odnosno gledaoca. Dok Stevan Koprivica motive i sižee pronalazi u dalekoj istoriji i legendama, Siniša Kovačević se fokusira na bližu prošlost. Velika drama obrađuje buran istorijsko-politički period u Jugoslaviji, nakon tek okončanog Drugog svetskog rata, od 1945. do 1948. godine i Rezolucije Informbiroa. Teško nasleđe iz ratom opustošene zemlje, koja je pored agresija spolja pretrpela i krvav građanski rat, surove ideološke i verske sukobe, umnogome oblikuju ambijent drame. Sve se to prelama kroz živote članova porodice preseljene iz crnogorskog krša u vojvođansku ravnicu. Kolonizacija Vojvodine odmah po završetku rata česta je tema u srpskoj književnosti druge polovine dvadesetog veka. Kovačević piše odista veliku dramu, sa preko trideset likova, komad epske širine, sa mnogim epizodama, čija je funkcija da oslikaju kompleksne procese stvaranja novog društva kroz psihološke i socijalne aspekte i lomove unutar mnogoljudne porodice. Veliki je i vremenski okvir dešavanja jer se Kovačević ne zaustavlja samo na tri posleratne godine, već događaji zadiru u najnovije balkanske traume u zadnjoj deceniji prethodnog stoleća, ilustrujući odavno poznatu tezu da su političkoideološke razmirice večiti pratilac srpskog naroda i njegov tragični usud. Ovu misao autor dodatno razrađuje i proširuje na celokupni prostor i narode bivše Jugoslavije u Janezu. Moglo bi se čak zaključiti da je Janez logičan epilog Velike drame, iako između ova dva teksta nema konkretnijih dodirnih tačaka. Zastavnik bivše Jugoslovenske narodne armije, po nacionalnosti Slovenac, traži utočište sa svojom porodicom u Beogradu, nakon raspada države i krvavog građanskog rata. Problem identiteta dolazi u prvi plan, jer iako ostaje veran zakletvi datoj još pokojnom maršalu Titu, vrhovnom komandantu i doživotnom predsedniku Socijalističke Federativne Republike Jugoslavije, i dalje verujući u ideale zajedničke države i narodne vojske, Janez Kranjc ipak je tuđin u negostoljubivoj sredini, izgubljeni apatrid, čija je sudbina iskonski povezana sa zemljom i vremenom koji nepovratno nestaju.

Kratak pregled savremene srpske dramske književnosti od 1995. do 2015. godine pokazuje izrazitu žanrovsku, stilsku, tematsku i poetičku raznolikost. Uprkos tome što se autori mogu grupisati prema generacijskom principu, ili na osnovu drugih parametara, kao što su primenjeni literarno-dramaturški postupci, odnos prema istorijsko-političkom kontekstu i pojavama u savremenom društvu, prihvatanju modernih evropskih dramskih obrazaca ili zadržavanju u sferama tradicionalnog dramskog pisma, pomenuta heterogenost jeste njihova glavna odlika. Stoga se u širem tumačenju i klasifikaciji može samo uslovno govoriti o kategorijama eskapizma i društvenog angažmana kao međusobno isključivih, jer su reprezentativna ostvarenja srpskih pisaca $u$ ovom periodu najčešće sadržavala elemente i jednog i drugog pristupa, odnosno, diskretnijeg ili eksplicitnijeg kritičkog razmišljanja o svetu u kojem smo živeli i u kojem i danas egzistiramo. 


\section{Literatura}

Predsmrtna mladost. Antologija najnovije srpske drame (1995-2005). Priređivači: V. Jezerkić S. Jovanov. Novi Sad, Sterijino pozorje, 2007.

Istorija \& iluzija. Antologija najnovije srpske drame (1995-2005). Priređivači: V. Jezerkić S. Jovanov. Novi Sad, Sterijino pozorje, 2007.

TAsić A.: Otvorene rane - telo u neobrutalističkoj drami i pozorištu. Beograd, Čigoja štampa, 2009.

Radonjıć M.: Sterija u ogledalu XX veka. Novi Sad, Pozorišni muzej Vojvodine, 2006.

Radonjić M.: Begunci iz beznađa. Novi Sad, Pozorišni muzej Vojvodine, 2017. 